\title{
Called to respond: The potential of unveiling hiddens
}

Dr. Alison L. Black ablack1@usc.edu.au

Early Childhood, School of Education, University of the Sunshine Coast, Queensland, Australia.

Dr. Sarah Loch sarah.loch@uts.edu.au

International Centre for Youth Futures, University of Technology, Sydney, Australia.

\section{Abstract:}

Interested in exploring how personal stories and aesthetic modes of representing experiences can nudge open academic and educational spaces, this article/collection of particles seeks to document our encounters of being affected and called to respond to things the other has written and represented. As a way of engaging with questions about what research and research data might be and become, our attention has been drawn to stories and images from our lives that we have not shaken off-and to how, as we have opened these to the other, making once private moments public, our hiddens have morphed tenderly into a shared knowing and being. As we have acted on the call we have felt to respond we have found ourselves entering spaces of collaboration, communion, contemplation, and conversation - spaces illuminated by what we have not been able to - and cannot - set aside. Using visual and poetic materials we explore heartfelt and heartbroken aspects of our educational worlds and lives, to be present with each other and our (re)emerging personal and professional meanings. We see the shared body (of work, of writing, of image) that develops from the taking of brave steps and the risky slipping off of academic masks and language, as a manifestation of the trusted and nurturing spaces that can be generated through collaborative opportunities to gather together. These steps towards unveiling hiddens are producing in us and of us a friendship, fluency, and fluidity as we write new ways of becoming. In turn, we hope the uncovering and revealing of our dialogue in the public gathering of this journal might supports readers' telling of their own life stories through what calls them to respond.

Key words: Identities, stories, aesthetic inquiry, personal/professional meanings and histories, reconceptualising research, becoming in research and research methods.

\section{What brings us to this place?}

As we engage in our daily lives we encounter other people, we engage in interactions, we build relationships. Educational work, education research, and teaching are also about relationship, interaction and connecting with human beings to engage compassion, ethics and communication (Noddings, 2012; Palmer, 1997). Whether we are acting intentionally or not, we are always part of these interactions, always contributors. Yet, so often in educational and academic work there is an assumption, an expectation, that professionals must veil who they really are (Michalec \& Brower, 2012). Too often it is communicated that educators and researchers must not be part of the stories 
they tell and so their presence is mostly characterised through their absence, through the invisibility of the lives they are living, in spaces filled with unspoken realities (Doty, 2010). As educators and researchers we want to resist this (perceived/real) stifling pressure. We want to write and speak from within the stories we have lived, are living, reliving and retelling. We want to do this with presence and visibility, vitality and activism.

Of particular interest to us in this collaboration is the way fragments of our teaching and researching stories are used to explore/trouble/dismantle/extend and (re)power our blurred and manifold identities (academic, teacher, parent, daughter, partner, friend, researcher). We take up Gilles Deleuze and Félix Guattari's (1987, p. 287) suggestion in A Thousand Plateaus to encourage the 'secret to sneak, insert, or introduce itself into the arena of public forms'. Our to-and-fro writing in the form of emailed conversation has been growing for one year now and our interest in the other's life creates opportunities through which secrets, or 'hiddens', shift in form as they detach from the teller and move into the other's discourse. In being un-covered and re-covered by the other, these once-hiddens become, as Deleuze and Guattari explore, active and unstoppable in the ways they resist containment and capture.

We each have our own reasons for wanting to unveil hiddens to bring greater visibility to our lives/work/identities. As Ali looks over her education-related life history she senses she has been engaged in an ongoing grappling with the wearying and 'deadening' systems, beliefs and practices that can exist in education and academe. More recently she has found herself joining with others to explore the metaphor of 'zombiedom' as a way of recognising and challenging her experiences of the narrow and more-dead-than-alive political, cultural and pedagogical viewpoints, accountabilities and restrictions that seem to be increasingly threatening and infiltrating academic and educational worlds (Ryan, 2012; Whelan, Walker, \& Moore, 2013). Ali realises at any time she both resists and succumbs to zombiedom. A means of survival? Personal worlds are continuously in tension with her working life - yet acceptable spaces to voice what is personal (and felt) in public/work/research arenas seem scarce. Meaning, purpose, and vitality feel suffocated by endless-mindless-demanding bureaucratic tasks and ideas. Work/life balance is mythical and unattainable.

Reflecting on education-related life history fragments, Ali has recovered events that continue to demand attention and articulation. Embedded in Ali's life story fragments are queries about 'aliveness', the teacher heart, wishes and dreams for education, children, and communities, as well as connections to values for education and teaching. Her 'five-year old first year at school self' tells her of the importance of knowing children and families. The cries of her 'eighteen year old preservice teacher self' struggling on prac while her mother lay dying echo in her memory, repeating the message that 'becoming' and 'being' are ongoing changing multifarious states linked to interactions, to feeling, to responding, to caring. In her stories that scatter experiences of life, longing, change, grief, loss and joy, she finds personal and professional meanings that attach themselves to her, that jar, that challenge and that offer ways of negotiating her blurred identities as parent, woman, daughter, teacher, researcher, academic, other (Giorgio, 2009; Hurd, 2010; Rolling Jr \& Brogden, 2009).

But is it risky for Ali to offer such a public acknowledgement of real life, of the life she has lived and is living, of relationships built and lost, of uncertainty, of pain, of becoming and unbecoming in education, in research, in academic work - especially when the demand seems to be that these worlds 'should remain separate'? (Black, 2015). Can they be separate when they are not, they are never...? Arising within is an activist. As an act of resistance to sources of zombiefication, Ali finds herself reading, writing and researching in shadowy spaces of deep emotion and experience (Black \& O'Dea, 2015; Hocker, 2010; Poulos, 2012; Richardson, 2013; Terry, 2012). She is finding connection 
through self-study, and autoethnography of sorts. But she is full of questions. Do our stories matter and to whom? Should we share our personal lives in the public domain? What happens if I reveal these stories? What happens if I don't? What is produced when stories are revealed? What is made possible? Should educational work ask us to set aside our personal and life experiences and compartmentalise ourselves, silence our thisness and withinness, and put on various masks/mask the personal?

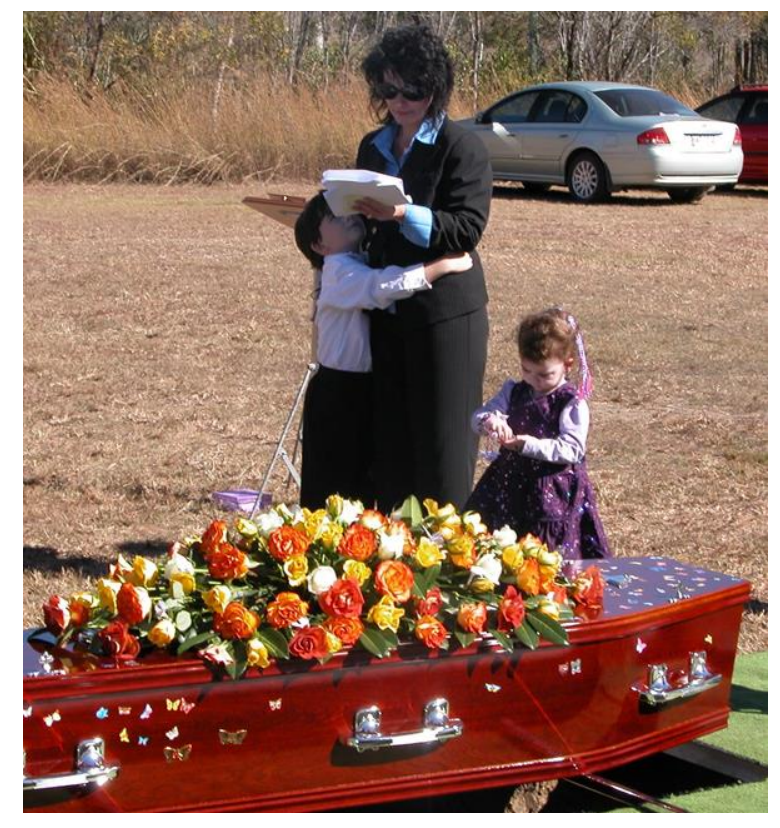

Do I - Can I - Should I - set this aside? Ali Black Personal photo 2006

Exploring these questions, Ali shared her writing with Sarah, a tentative sharing. What do you think, Sarah? Ali and Sarah's connection to the other came - significantly - through text and voice. We came into one another's lives through a writers' workshop where the purpose was to give one another feedback on our work.

Sarah was drawn to Ali's explorations of identity and career as in Ali's almost unspeakable, but being-spoken, stories Sarah was witnessing another woman's interaction with the sticky silence of self. In fragments which began to voice the deep ellipsis with which she commonly negotiates and separates her educational and personal lives, Sarah began following Ali's hiddens to see what would happen if she used the co-produced momentum to prod and push open some hiddens of her own. Sarah's secrets gather around her body and uncomfortable positions in which she has found herself as she has moved through life and work as a school teacher. A few years ago, she made the decision to leave her 'safe' job as a teacher to embark on a PhD and to safely deliver a long tried for baby. She felt she needed to free herself from the schooling sector; a sector that can discriminate when you are in a gay relationship, a sector that can't always accommodate the demands of IVF, a sector that likes the sound of a dissertation but struggles to provide scope to grow within and from such a project. Leaving full time work, although financially risky, seemed the only way to achieve both these goals and, indeed, in time both Sarah's baby and academic qualification eventuated. But the life stories inked on one's soul through 'lesbian', 'PhD' and 'IVF' are particularly relentless and persistent. These labels flag the sleeping stories which have often seemed too subterranean to bring to language. They are the stories that go 'through the belly, through the entrails, through the chest' 
(Cixous \& Calle-Gruber, 1997, p. 46). It was in this space of reading the production of her body differently that Ali's stories called Sarah to respond. Heartbeats.

\section{Laying down landmarks; turning up tender pink bellies}

In writing about ways our spaces and identities are defined, claimed and negotiated and ways that we call others into them, we look to images including Deleuze and Guattari's reference to the brown stagemaker bird, known also as the tooth-billed bowerbird. This Australian rainforest bird 'lays down landmarks each morning by dropping leaves it picks from its tree, and then turning them upside down so the paler underside stands out against the dirt' (Deleuze \& Guattari, 1987, p. 315). Is this what Sarah and Ali are doing? In calling and being called to respond, are they turning upwards a tender pink belly to let others know they are here?

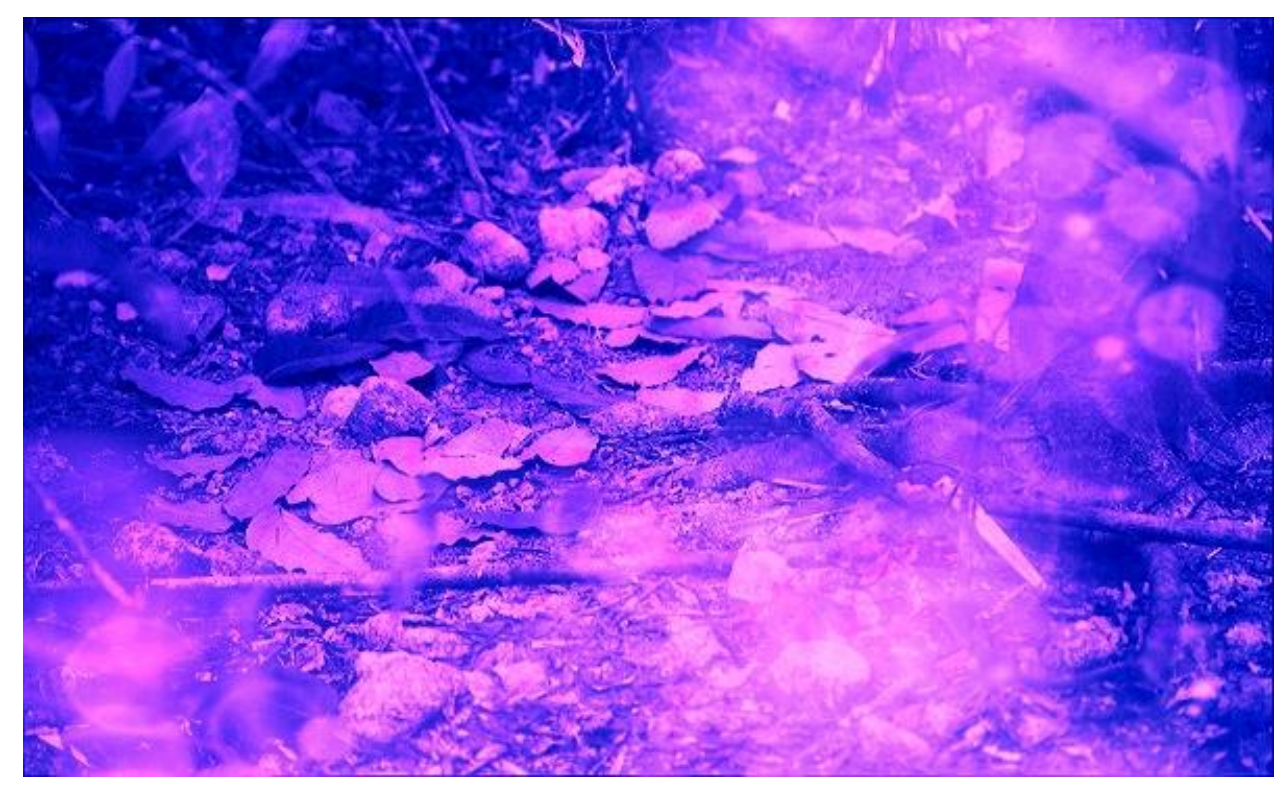

The bower of the tooth-billed bowerbird marked out by up-turned, freshly cut leaves Image digitally modified and coloured. Original source:

http://birdway.com.au/ptilonorhynchidae/tooth_billed_bowerbird/source/toothbillbowerbird_154937.htm

Our reciprocal sharing, of not just intellectual work but the everyday particles and landmarks of our lives, has lead us to consider ways our 'up-turning/turning-upwards' positions us as agentive in the entire process of unveiling. Charles Stivale $(2008$, p. 35) queries, 'what is the thisness of the pedagogical exchange, and how do becomings occur?' In responding both quickly and more intentionally to one another's stories about schooling and teaching, a 'stammering' and 'stuttering' is generated which sends a tremble through our collaborative becoming as co-writing academics. The notion of thisness, in which we ourselves are the trail of daily turned up leaves, is important because at other times we have written from the sides or from other places, unable to see in ourselves the rhizome of haecceity (Deleuze \& Guattari, 1987). Within 'the thisness of the pedagogical exchange', where nestles our writing about our stories of education, our bodies negotiate educational space differently as we enter writing which knits our classrooms and homes into the stories we need to tell and the questions we cannot ignore. 
Clustering our email conversations around our 'formal' writing, we have accumulated enough material for a book. Our emails, Sarah's poems (Loch, 2015) and Ali's images (Black, 2015; Black \& O'Dea, 2015), have connected the in-between spaces in which we are living - spaces between employment, between IVF processes, between hope and next-time, between overwhelm and breathing, the everydayness of putting our children to bed or dinner on the table, spaces between significant life events and change. Our writing, formal and informal, has encouraged self-emergence, raw truths, honesty and troubling. It has encouraged us to dismantle our educational understandings and provided provocation to look again at our experiences and not gloss over them. These provocations have been complex, unexpected, and profoundly meaningful. And Sarah and Ali have still never met in person.

For Sarah, disclosures she had thought irrelevant to academic life have tumbled out as she realised Ali, an academic, wrote about the thisness of her life: employment, unemployment, workaholism, teaching, academia, death, birth, parenting, juggling, and processes of being/becoming/unbecoming in all of these experiences.

For Ali, having Sarah lay down landmarks, too, having her join in the tender belly turning of private and delicate stories, there has been a renewed realisation of ways that nurturing spaces are generated when people trust and explore stories together. Between us there has grown a strong sense of recognition and personal renewal despite our continued uncertainty, motion and emotion linked to our shifting, complexly connected identities and our unending, always becoming into these identities. Sarah, witnessing Ali's struggles in the very spaces she desires for her own work identity, has found in conversational dialogue a counterpoint, an echo, a conscience, a nudge towards questions about 'living meaningfully' (a term Ali often ponders in her emails).

This assemblage, coming together through crisscrossing emails and skype calls, has brought with it reflection and change in the ways we continue to be produced as friends by our interactions. Our collaborative and supportive becoming, similarly described by Ken Gale and Jonathan Wyatt (2009, p. 3) as the ongoing act of 'learning to work between the two of us', has seen our sharing become embodied, welcome and nurtured. The feelings we have about writing together are just as important to this emerging writing-space as the information we share of our lives and the responses we receive. We have now lost the awkward, new correspondent feeling of wondering how to sign off each email and are benefiting from knowing some of the history behind the situations of which we inquire, but we remain interested in troubling why trustful sharing is so generative and useful, and how trust and tenderness come about. Collaborative writers, Wyatt, Gale, Susanne Gannon and Bronwyn Davies, with Norman Denzin and Elizabeth St. Pierre (2014), point to the blurring of boundary lines and feelings of immersion and intensity that bring different lives into relation with the other. Our focus falls on the highly inter-active patterning of what is happening here - brave offerings to perforate the academic skin of our relationship, listening heartily to the other's wonderings and recognising how, as writer and reader, we have found lifeblood in 'the mundane, the taken-for-granted, the whispered, and the hushed' (Laura, 2013, p. 290) which had previously slid between folds in our writing.

Reading Ali's work, Sarah has found herself considering the cusp-like, insecure stance of beginning to work as a casual academic. The tentative, never-quite-but-almost, never-ending positioning of the woman as casual academic (Crimmin, 2014) is a stance with which Sarah has been struggling recently. Drawing closer to the submission of her own thesis (Loch, 2014), Sarah began sharing with Ali the hopes and fears she held over what she might do next with a young child, new PhD, limited publication record, dwindling finances and seemingly limited prospects of tenured employment at a university. Waves of grief came when she weighed up leaving the intellectually and creatively 
generative spaces of her writing for the 'safe' prospects of returning to a school. In this space of notknowing, Sarah has connected to the 'line of escape' (Deleuze \& Guattari, 1986, p. 86) flung out by Ali's risky writing as it helps bring language to the deterritorialisation she has been experiencing as she stutters between the value of leaking personal/professional experiences and trying to keep identities contained. In writing out memories and telling stories to and between one another, the lines Ali and Sarah create and take are not necessarily escapes from stricture to freedom. As Deleuze and Guattari (1986, p. 86) write, 'suppleness can be as constraining and more crushing than rigidity' and with this comes recognition that the act of revealing a hidden story is not necessarily emancipatory. It is what happens next and how one is changed by the vulnerability and exposure of the process that makes sense of the risks associated with escape.

Ali's early particles:

"You need to get over it..."

I was five years old and in my first year of school. Coming to the veranda to get my school bag I found George, a boy in my class, guffawing as he kicked my bag up and down the floorboards. Before coming to school I had joyfully stuck a wonderful big ladybird sticker on my bag. George's kicking spree now left it scratched and ruined. I was distraught, in disbelief, devastated. The teacher arrived. George was reprimanded but there was very little sympathy or understanding - it was "just a sticker" on a bag, "calm down Alison, you need to get over it!"

This was a frightening year for me and I am sure I presented as a frightened little girl. When you are new and small primary school can be intimidating and a lot to make sense of. But there was more to it - did my teacher really not know? My mother had experienced kidney failure and needed a transplant. I had overhead people saying she would die. We lived in a regional area and the local hospital had no facilities for dialysis. So she was living away in the city indefinitely, undergoing dialysis and waiting for a kidney donor. Both parents were away. I was living with my Grandma. Mum sent me precious letters written in multi-coloured crayon and sometimes a treasured present. The ladybird sticker for my school bag was the precious gift just received from her. It was so much more than "just a sticker".

"You better put on a mask and perform..."

During my final prac placement as a pre-service teacher I was placed at a kindergarten with an older teacher called June. I was eighteen. In terms of family it was pretty much just mum and I. She was often ill and emergency situations were common. At the time of this prac, mum had caught a serious infection and was suddenly dangerously ill. As puzzled doctors engaged in a myriad of tests, surgery and procedures to save her life, I attended my practicum. I believed that this final prac was crucial in terms of being able to graduate and that I had no alternative but to complete it. I wish someone had intervened and helped me. June wasn't compassionate or responsive when I explained what was happening. Instead she demanded I put everything I had into being engaged and animated with the children. I was warned against being quiet or withdrawn and told my prac - and my ability to graduate - would be at risk if I didn't perform.

During the second week of my prac block, doctors advised me that mum was unlikely to make it through the night. Their recommendation was that I stay - and be with her till the end. We had been through a lot. We loved each other fiercely. She was my best friend. In the middle of the night, overwhelmed with grief and fear, I walked into the darkness outside the hospital ward and broke down. I can still hear my sobs. I can still feel the terror and the anguish. 
Thankfully my mother did not die this night, but outcomes were precarious. June's response upon hearing about my overnight vigil was that I needed to demonstrate attentiveness and enthusiasm and be bright for the children. She threatened to fail me if this was not accomplished. The repeated message I received was that the activity of being human wasn't valued and had to be put aside for the sake of the children. Now, as a parent, I have experienced first-hand how responsive young children can be, how capable they are, how they want to comfort and share in sorrows, how they want to engage in the authentic activity of being human (Silin, 1995). June could have communicated an ethic of care and created conditions of compassion and respect. She could have communicated that learning to teach is a life-long process of becoming, an ongoing process of negotiating relationships, identities, personal and professional experiences. She had an opportunity to empathize with my life situation and offer gentle understanding and kindness. But she did not. Perhaps she hadn't considered what a socially relevant and responsive early childhood curriculum might look like, or the opportunities afforded by the stories and difficult times in our lives (Noddings, 1992, 2012; Richardson, 2011).

\section{The scattering of a dandelion}

Ali's stories felt relevant to Sarah. They felt relevant for her as a beginning academic and as a woman with a child. So real, Sarah couldn't get Ali's stories and pictures out of her head and they kept returning to her, throughout the period spanning the writers' workshops and beyond. They made Sarah reflect on the value of 'returning' - of returning to frightening educational spaces with readers who stand alongside in support, of the value of stories for children and young people having similar experiences. In turn, Sarah told Ali her own stories: her first teaching job and the loss of her father in the first two years of teaching - like Ali's mum, Sarah's dad had kidney failure and was undergoing peritoneal dialysis. But, after relatively simple surgery to prepare his body for the more intensive level of haemodialysis, complications struck and he never came home from hospital.

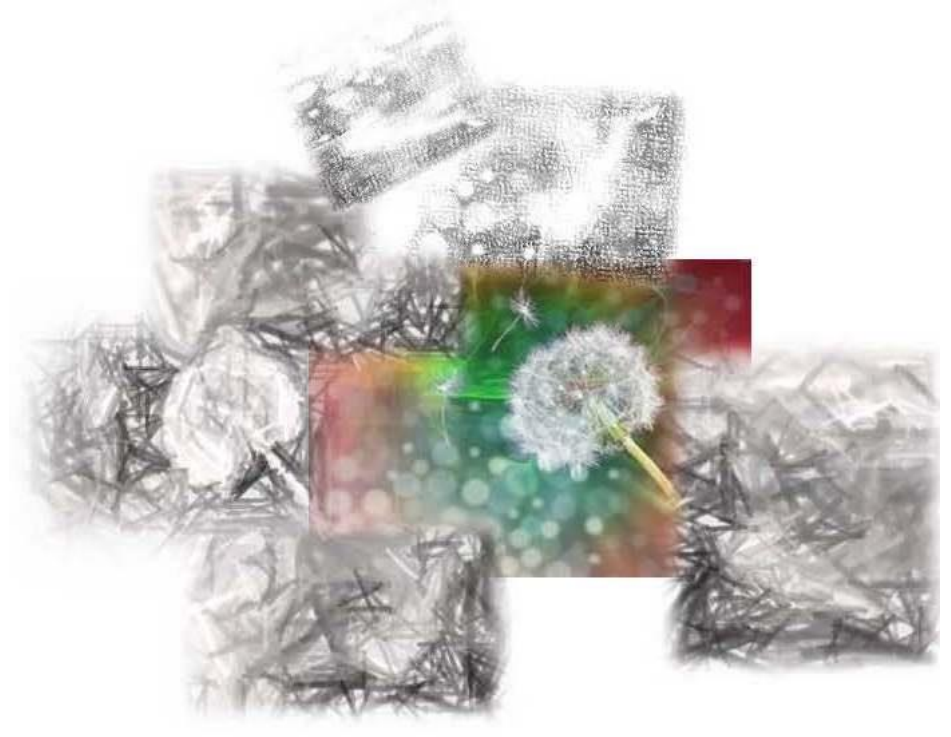

Stories don't stop at the telling. It's in the uptake, the scattering of the dandelion. Ali Black Digital artwork 2014 
Months after reading and sharing these articles, particles of stories linger. They (re)emerge in reflection, in everyday encounters, and in conversations with others. Particles are scattered and scattered again. What matters becomes real (Loughran, 2007; Richardson, 2001).

It was many months after Sarah had first encountered Ali's tentative tellings that she felt called to communicate to Ali that these stories were enduring, were staying with her and stirring up within responses and recollections of her own related particles. The following response illustrates how the rolling exchange, dialogue and reflection began:

Sarah to Ali:

I'm writing here to let you know that your 'Authoring' chapter (Black, 2015) has affected me and has seeped into my thinking about teacher education, and particularly how one becomes a teacher. I'm not sure how writing your chapter has affected you and am not fully aware of how it has affected me, but it does seem important to let you, the owner/author know, that your stories did not stop in the submission of your work. It's in the uptake, the scattering of the dandelion. And it does seem important to say something that lets you know I'm here and that I've read what you wrote. In this responding, I am writing to pieces that have not left.

The most luminous and pulsing story is the one about your first day at school. The ladybird sticker lovingly bought for you by your mum who was in hospital so far away, your first day at school with the sticker on your bag, the boy kicking your bag, wrecking the sticker and the teacher telling you to stop being a baby, to stop crying, to get on with things, to 'begin school'. What an introduction. To 'education'. I have been called to respond through my remembering and re-thinking, and re-telling of this story for my own purposes, such as to students in my Philosophical and Ethical Practice in Education class. Perhaps this has been a way to connect with you and to say I would not have done that, been that teacher, and that if I could change that first day, I would.

I saw a large red and black ladybird sticker in a museum shop and had it in my hand to buy for you, but I put it back. I became conscious of our research relationship. Although we've been in touch and helped each other with material for our respective job applications, and have talked warmly and excitedly about writing collaboratively, I wasn't sure whether sending you this symbolic sticker in the post would go too far. You shared a story which I have taken and retold. But in giving you thanks, I didn't want to go too far. But, really, what does that mean?

Ladybird sticker

I see a story in the red roundness

A little girl in 1st grade

A bully boy lets out a laugh, his leg swings back

Collides. Boot. Your school bag with the ladybird sticker

Luminous, shiny plastic; sliding, red and black tumbling scratching spinning

Tearing.

This is the gift, dangling,

Violated

Entered by the boy with the boot, stomped by 
Teacher in those words. Stop. Crying

'It's only a sticker, Alison'. It wasn't

only a sticker, Teacher. It was

Alison's mother's love-gift to her little girl, gently and perfectly

chosen from the florist stall

the newsagent in the foyer, somewhere in the hospital

when she couldn't be there.

And you, Teacher,

You let her down.

Ali to Sarah:

You know that I have wondered whether my personal stories should be revealed and what, if anything, they might produce or make possible in their revealing? I could not have imagined the consequences that have eventuated for me in the connections we have found in sharing and responding. I could not have imagined the vital and emotional currents that your poems 'Ladybird sticker' and 'June' would create for me and encourage in me. Having you acknowledge these stories and respond in these ways to my writing and disclosure has been so meaningful for me. To know you have contemplated buying me a ladybird sticker...that you 'get' the significance of this experience...that you 'get' me... yours is such a gesture of healing, of tenderness and kindness. June was unable to extend that to me. But, you have. I have felt a welling of emotion to know that in seeing a ladybird sticker you have felt called to respond to me. Now I have another (different) ladybird story which I remember upon every new ladybird encounter. Thank you Sarah. And, just the other day, my daughter and I found ladybirds all along the beach. As we walked she picked them up. She rescued them from waves rolling in. She became my ladybird princess as dozens took refuge on her skin and crawled up her arms. Ladybirds, no longer linked to just painful memories, have morphed into laughter, magic and hope.

I am glad I have been brave and let slip the mask June urged me to wear (or else). You have responded not just to stories, but to me. You have listened. You have understood. You have set aside time for caring. You have given time to creating poetry and to opening spaces for reflection and shared inquiry. You have recognised the value of stories and passed them on to others. You have found courage to share your stories with me in return. (Be)coming together. Communion.

Sarah, you say that you have attempted to offer responses to make up for the past and prove not all teachers would be the same. You say that you have moved yourself to ways of responding that would not have existed had I not written of my pain. I say I am glad I have troubled these stories that have affected me - they called you to respond, and your responses have brought me such gifts. 


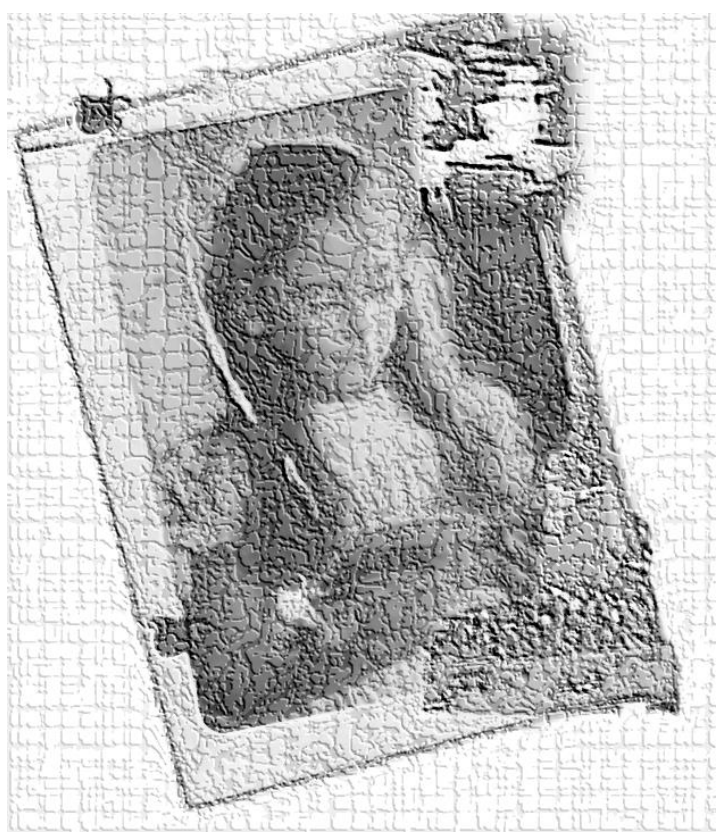

(Re)Piecing/peacing fragments of life stories Ali Black Digital artwork 2014

Sarah to Ali:

Ali, I told my students the story of your supervising teacher, June. In supervising your final prac she threatened to fail you if you didn't pull yourself together and act happy, as you lived afternoons, evenings and weekends in a hospital with your mother as she courageously and successfully fought a terrible illness. The students relate to this story as many, too, have had 'bad pracs' and are valiantly trying to make sense of power and positioning and the vulnerability of being assessed in relation to a career they are imagining. Not yet 'teachers', but, when on practicum, no longer 'just a student', I would like my group to think how a teacher - this singular body they may wish to become - will never simply and singularly be that. Deleuze and Guattari (1987) explore the connections and multiplicities of assemblages and I wonder if my students will pick up on how 'put together' I see ourselves to be. As I tell your story, I sense many relate with relief to images of the 'assembled teacher' and have been (re)living their own version of your vigil, your practicum, your anguish as I chat on. Many have their own stories to tell and I hope my interest in your story shows I will be interested in theirs.

On my final prac in 1998, my house was broken into and I was robbed. The house was cleaned out, everything of any value was stolen. Looking back, this event was the trigger for a longer string of falling apart as my then boyfriend and I moved into temporary accommodation, before encountering our own breaking up. Then, my own shocked silence as I fell in love with a woman at my school and was gradually brought back together. At the time of the robbery, I was worried about the senior English essays I had just marked but they had been left untouched on a sideboard. I didn't tell many people at school the next day about the robbery. I didn't want to appear weak. But in terms of storytelling, I don't think I could even make that into a small tale. I certainly didn't have a 'June' and I tend to let slip away the stories I should probably tell.

June

Ali, I see you at kindergarten, almost a teacher, 
your final prac, smiling and bright

The children love you, Ali, of course!

But I see June in the corner. She watches, clipboard rigid,

judging,

you stutter slightly over something small

when she lurches forward, waiting to fail you

she says

For a lack of shiny brightness

For loving your mother (when she did not love hers?)

For being there all night,

in hospital again.

holding her hand

so close to the end.

I can feel the reeling, exhausted grief.

I did the same for my father

every night for two weeks,

the pointy end of over five years of illness,

I did this until I went numb.

Then we came up against the end.

But, not-you, I wasn't doing my prac

the essays I lugged back and forth to mark were decoys to death

the normal pace and proof of a teacher uninterrupted

my teacher-colleagues supportive.

In the weird space of prac

you whirled alone

grief untethered from the place where you were

to the children who knew you were there. 
The reason I have been re-telling and re-presenting your stories on my own plane of understanding has been to make the point that sometimes we become a teacher and choose teaching as a career out of and alongside places of unimaginable pain and dislocation. This comes not from my own becoming-teacher which, as I think of it, was more of a rolling and unfolding than the jagged journeying you encountered. (And remember, I tend to let slip away the stories I probably should begin to tell). So, I have borrowed you a little in that boasting way of being able to tell of something that happened to someone else. I have tried to use your becoming-teacher to illustrate for my students how differently we move into ourselves as teacher and perhaps, through my talking and my students' unpredictable responses, I can come to something of what you might have felt. Is this the doubleness of becoming to which Deleuze and Guattari (1987) refer? Borrowing from you, giving to others, sense-ing myself within the ever-shifting assemblage of how I am being produced?

Polyvocal, I respond to this call. Called to respond. It's always a beginning.

\section{Teaching as a form of friendship}

Sarah's poems have been a way of affirming that, more than just having read, she has been reading Ali's writing and experiences and by way of response, wants to keep listening. St. Pierre (Wyatt et al., 2014 , p. 8) notes ways that ethical relationships like these are troubled by the processes of reading, writing, and reading writing as we query how much of someone else's story could be ours to tell and when and whether a story of ours could be of use to another. The relational aspect of writing and reading which is inclusive of uncontained and unfinished relationships with people, places, events, memories and dreams, and which works in spaces of teaching similarly incomplete and imprecise, ushers in Hélène Cixous' (1993, p. 12) call to 'think through each relationship'. 'We can think this through', Cixous suggests, 'with the help of writing; if we know how to write, if we dare write'. The point of this paper has been to explore this daring feeling by encouraging in our conversation sensitivity to the responses that come when one's writing is pushed further by the process of listening to and engaging with another. As our sharing opens spaces for new stories to be told in lives moving rhizomatically 'as open, multiple and becoming spaces' (Olsson, 2009, p. 42), our sharing itself becomes a safe, trusting pooling of friendship - a harbour amidst the entrepreneurial contortionism expected of the neoliberal academic (Davies \& Bansel, 2007).

Attempting to counter the threat of zombiedom, the sharing represented in the images, poetry and reflections of this paper are unfolding 'in the soul', heading towards envelopment (Deleuze, 1993, p. 23). The folds add emphasis along the crease lines of daily things, which lead to recognition, acknowledgement, provocation, discussion and pause. The records we keep of our ongoing conversation leave a tender trail of who we have been and are becoming amidst what becomes a scattering and stuttering of interrupted and often unfulfilled/unfillable imaginings - such as the workloads we manage, the jobs for which we apply, the time we take from our families, relationships with the parents we have lost. The story-fragments we exchange, from memories of our childhoods, teaching histories, career journeys and life paths, are folded over and over with our imaginings; our friendship leading us to 'the enveloping envelope that touches an infinity of curves in an infinity of points' (Deleuze, 1993, p. 22). Then, new 'peaces', like Ali's daughter's ladybirds, contribute a new point of intersection.

Is this how a friendship begins?

Friendship in this methodology began with co-created spaces of conversation but the 'rhythm' of responding has moved us, somewhat unexpectedly, to richer contemplation and communion. 
Deleuze spoke of teaching itself as a form of friendship, with recognition of finding, 'someone who suits us, who teaches us something, opens us, awakens us, rendering us sensitive to an emission of signs' (Stivale, 2008, p. 81). Simply, our efforts are nurtured and encouraged by our trust that the other will respond if we write and by having confidence in what could otherwise be uncertain, we locate ourselves in the thisness of exchange; in 'relation [to] movement and rest, speed and slowness, by a combination of atoms, an emission of particles: haecceity' (Deleuze \& Guattari, 1987, p. 276).

What is it we have noticed as our stories have come together? Can they matter to circles of people beyond ourselves? Will they continue onwards to unsettle other stories of work and learning, and can they provoke in others the thisness and withinness we have found so generative in spaces unknown and unexpected? Our unveilings have caused much to happen with-and-in our writing. We have taken risks to return to stories we had left unturned. We have exposed our underbellies by leaving trails of tender fragments, turned up, destined to be seen. We have nudged open spaces for secrets to become stories and for containments to slip out. Yet, in the uncovering processes of writing and in the public forum of this journal, have found in fear, restraint and pain a reason not only to respond, but to speak.

With our writing

With our writing I am finding a meeting space, a sacred ground.

A starting place? Or, rhizomatic, we go round and round ... and in between, in spaces previously not revealed, unoccupied by educational others. I trust you.

Becoming, unbecoming, who am I? What do I bring? Uncertainty. This is me, and this is you. In our un/be/coming there is relationship. Together we bring the unravelled and honest threads of everyday and knit ourselves into something shared and warming.

Our musings and questions spin something important within and beyond. This communion of uncertainty brings something certain - connection, resonance, authenticity, awareness.

We are sharing a language, of gaps, transition, ache, hope, dread, troubling, not knowing.

It is real, it is a balm. This writing space is a healing space for me. Resonance. Vulnerability. Imperfect lives connecting and inhabiting each other's stories.

I am encouraged. This is meaningful to me. This (e)motion is what matters in my educational work. It is like finding a diamond on a keyboard.

Thank you. I want this thread to go on and on. The weaving of words connects me to myself and to what matters. 


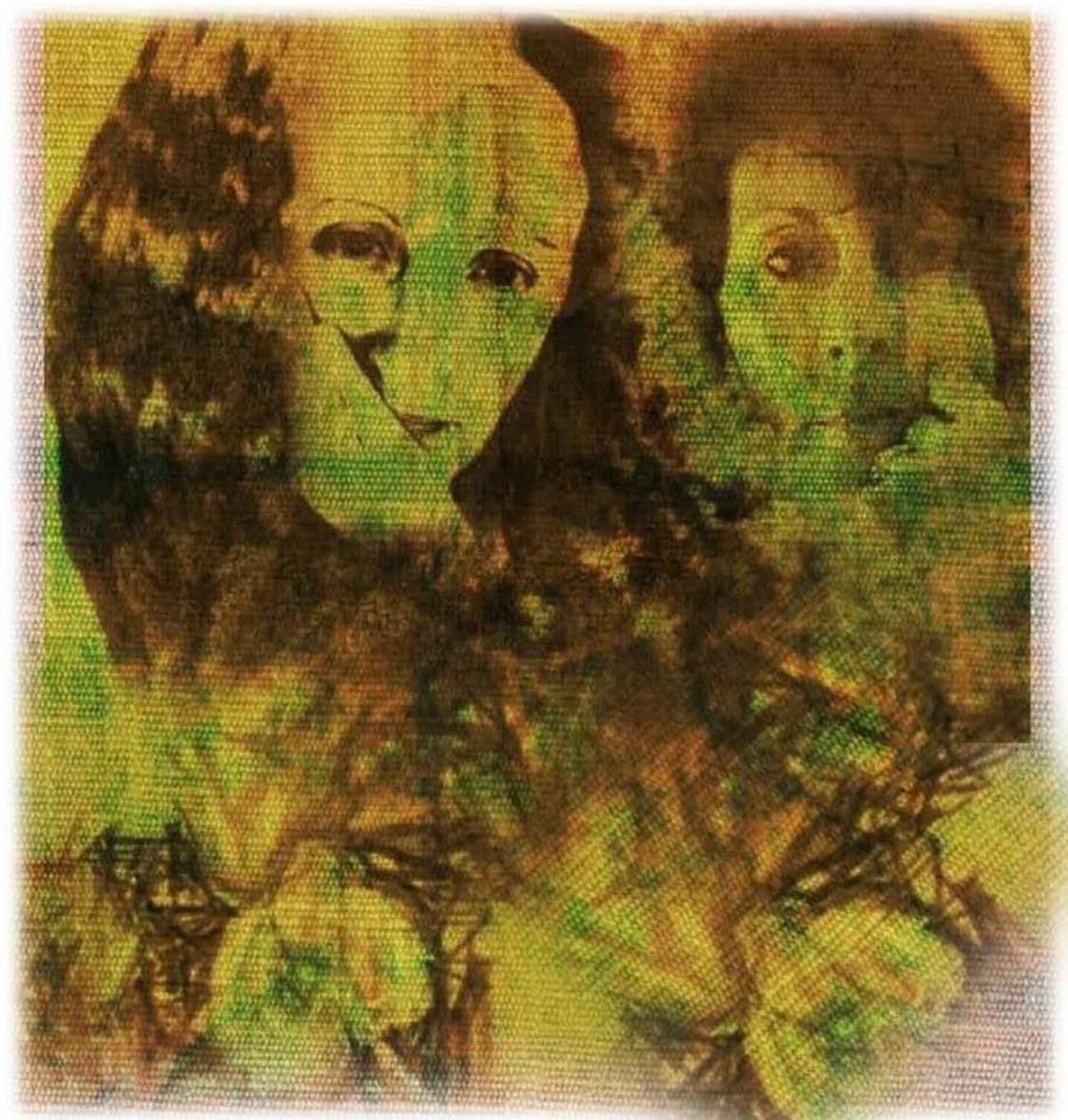

This is me and this is you

Knitted into something shared and warming.

Is this what research and research data can be and become?

Collaborative Digital collage 2014

\section{References}

Black, A. L. (2015). Authoring a life: Writing ourselves in/out of our work in education. In M. Baguley, Y. Findlay \& M. Kerby (Eds.), Meanings and Motivation in Education Research. London: Routledge.

Black, A. L., \& O'Dea, S. (2015). Building a tapestry of knowledge in the spaces in between: Weaving personal and collective meaning through arts-based research. In K. Trimmer, A. L. Black \& S. Riddle (Eds.), Mainstreams, Margins and the Spaces In-Between: New possibilities for Education Research. London: Routledge.

Cixous, H. (1993). Three steps on the ladder of writing (S. Cornell \& S. Sellers, Trans.). New York: Columbia University Press.

Cixous, H., \& Calle-Gruber, M. (1997). Hélène Cixous, Rootprints: Memory and life writing (E. Prenowitz, Trans.). London: Routledge.

Crimmin, G. (2014, 30 April ). [Scene 2, Act 2: Scene from unpublished thesis].

Davies, B., \& Bansel, P. (2007). Neoliberalism and education. International Journal of Qualitative Studies in Education, 20(3), 247-259. http://dx.doi.org/10.1080/09518390701281751

Deleuze, G. (1993). The fold: Leibniz and the baroque (T. Conley, Trans.). Minneapolis: University of Minnesota Press. 
Deleuze, G., \& Guattari, F. (1986). Kafka: Toward a minor literature (D. Polan, Trans.). Minneapolis: University of Minnesota.

Deleuze, G., \& Guattari, F. (1987). A thousand plateaus: Capitalism and schizophrenia (B. Massumi, Trans.). Minneapolis: University of Minnesota Press.

Doty, R. L. (2010). Autoethnography - Making human connections. Review of International Studies, 36(4), 1047-1050. http://dx.doi.org/10.1017/S026021051000118X

Gale, K., \& Wyatt, J. (2009). Between the two: A nomadic inquiry into collaborative writing and subjectivity. Newcastle Upon Tyne, UK: Cambridge Scholars Publishing.

Giorgio, G. (2009). Traumatic Truths and the Gift of Telling. Qualitative Inquiry, 15(1), 149-167. http://dx.doi.org/10.1177/1077800408318300

Hocker, J. L. (2010). It's all come down to me: Meaning making with family artifacts. Qualitative Inquiry, 16(10), 863-870. http://dx.doi.org/10.1177/1077800410383127

Hurd, E. (2010). Confessions of Belonging: My Emotional Journey as Medical Translator. Qualitative Inquiry, 16(10), 783-791. http://dx.doi.org/10.1177/1077800410383117

Laura, C. T. (2013). Intimate inquiry: Love as "data" in qualitative research. Cultural Studies <=> Critical Methodologies, 13(4), 289 - 292. http://dx.doi.org/10.1177/1532708613487875

Loch, S. (2014). Unfolding becoming: An invitation into the future imaginings of middle school girls, interlaced with my own journey to researcher. (PhD), University of Queensland, St Lucia.

Loch, S. (2015). A story of poetry and its provocative place in re-presentation In K. Trimmer, A. Black \& S. Riddle (Eds.), Researching mainstreams, margins and the spaces in-between: New possibilities for education research. London: Routledge.

Loughran, J. (2007). Researching Teacher Education Practices. Journal of Teacher Education, 58(1), 12-20. http://dx.doi.org/10.1177/0022487106296217

Michalec, P., \& Brower, G. (2012). Soul and role dialogues in higher education: Healing the divided self. New Directions for Teaching \& Learning, 2012(130), 15-25. http://dx.doi.org/10.1002/tl.20014

Noddings, N. (1992). The challenge to care in schools: An alternative approach to education New York : Teachers College Press, c1992.

Noddings, N. (2012). The caring relation in teaching. Oxford Review of Education, 38(6), 771-781. http://dx.doi.org/10.1080/03054985.2012.745047

Olsson, L. M. (2009). Movement and experimentation in young children's learning: Deleuze and Guattari in early childhood education. Oxon UK: Routledge.

Palmer, P. J. (1997). The heart of a teacher: Identity and integrity in teaching. Change Magazine, 29(6), 14-21. http://dx.doi.org/10.1080/00091389709602343

Poulos, C. N. (2012). Life, Interrupted. Qualitative Inquiry, 18(4), 323-332. http://dx.doi.org/10.1177/1077800411431565

Richardson, L. (2001). Getting personal: Writing-stories. International Journal of Qualitative Studies in Education (QSE), 14(1), 33-38. http://dx.doi.org/10.1080/09518390010007647

Richardson, L. (2011). Hospice 101. Qualitative Inquiry, 17(2), 158-165. http://dx.doi.org/10.1177/1077800410392340

Richardson, L. (2013). Twelve uneasy pieces on research and therapy. Qualitative Inquiry, 19(1), 2026. http://dx.doi.org/10.1177/1077800412462979

Rolling Jr, J. H., \& Brogden, L. M. (2009). Two hours or more away from most things: Rewriting identities from no fixed address. Qualitative Inquiry, 15(7), 1139-1154. http://dx.doi.org/10.1177/1077800408314342

Ryan, S. (2012). Academic zombies: A failure of resistance or a means of survival? Australian Universities' Review, The, 54(2), 11. 
Silin, J. G. (1995). Sex, death, and the education of children: Our passion for ignorance in the age of AIDS / Jonathan G. Silin ; foreword by Madeleine R. Grumet: New York : Teachers College Press, c1995.

Stivale, C. (2008). Gilles Deleuze's ABCs: The folds of friendship. Baltimore, MD: Johns Hopkins University Press

Terry, A. W. (2012). My Journey in Grief. Qualitative Inquiry, 18(4), 355-367.

Whelan, A., Walker, R., \& Moore, C. (2013). Zombies in the academy: Living death in higher education. Bristol: Intellect Books.

Wyatt, J., Gale, K., Gannon, S., Davies, B., Denzin, N. K., \& St. Pierre, E. A. (2014). Deleuze and collaborative writing: Responding to/with "JKSB". Cultural Studies $\Leftrightarrow=>$ Critical Methodologies, 1-10. 